\title{
Antimicrobial Characteristics of Untreated Wood: Towards a Hygienic Environment
}

\author{
Muhammad Tanveer Munir'1, Hélène Pailhories'2, Matthieu Eveillard2 ${ }^{2}$, Florence Aviat ${ }^{3}$, \\ Didier Lepelletier ${ }^{4}$, Christophe Belloncle1, Michel Federighi5 ${ }^{*}$
}

${ }^{1}$ Laboratoire Innovation Matériau Bois Habitat Apprentissage (LIMBHA), Ecole Supérieure du Bois, Nantes, France

${ }^{2}$ ATOMycA, Inserm Equipe Avenir, Inserm U892, CNRS 6299, Université Bretagne-Loire, Centre Hospitalier Universitaire, Angers cedex, France

${ }^{3}$ Your ResearcH-Bio-Scientific, Le Landreau, France

${ }^{4}$ Laboratoire MiHAR EE 1701 S, Institut de Recherche en Santé 2, Université de Nantes, 22 boulevard Benoni-Goullin, Nantes, France

${ }^{5}$ UMR INRA 1014 SECALIM, Oniris, route de Gachet, CS 40706, Nantes cedex 03, France

Email: *michel.federighi@oniris-nantes.fr

How to cite this paper: Munir, M.T., Pailhories, H., Eveillard, M., Aviat, F., Lepelletier, D., Belloncle, C. and Federighi, M. (2019) Antimicrobial Characteristics of Untreated Wood: Towards a Hygienic Environment. Health, 11, 152-170.

https://doi.org/10.4236/health.2019.112014

Received: December 18, 2018

Accepted: February 12, 2019

Published: February 15, 2019

Copyright $\odot 2019$ by author(s) and Scientific Research Publishing Inc. This work is licensed under the Creative Commons Attribution International License (CC BY 4.0).

http://creativecommons.org/licenses/by/4.0/

(c) () Open Access

\begin{abstract}
Wood, as a contact surface, has been used for centuries but is usually questioned because of its porosity and organic composition. It has natural antimicrobial properties and, hygienically, can stand the comparison with other materials such as plastic, glass and steel. In this review, we focused on potential microbe-inhibiting properties of wooden surfaces being used in hygienically important places like health institutes and food industries. This article addresses the questionable properties of untreated wood like hygroscopicity, porosity, roughness and chemical composition, and their relation to the hygienic and antimicrobial nature of this material. The other factors linked to the hygienic properties of wood, such as age, species and type of wood, have also been discussed. Our analysis of literature will create better understanding for acceptance of wood as a safety renewable resource. It also provides an outline for future research considering wood material in critical healthcare or food industries.
\end{abstract}

\section{Keywords}

Wood, Antimicrobial Characteristics, Physicochemical Properties

\section{Introduction}

Hospitals, healthcare facilities and food industries are confronted daily with the problem of transfer of contamination, especially from the solid surfaces of infra- 
structures, tools and equipment. In this context, surface hygiene is an important aspect for prevention of environmental contamination/infection [1]. These surfaces have different properties according to their constructing material such as wood, glass, steel and plastics [2]. Wood is a commonly used renewable resource in construction of these contact surfaces despite its reputation of a non-hygienic and non-cleanable material. In the last decades, several studies proved that wood is a better surface to control microbial growth and minimize microbial transmission [3] [4] [5] [6] [7], and aid the psychological welfare of inhabitants when used for indoor construction [8] [9] [10].

As previously described, wood naturally contains a microbial population according to its moisture content, decay status and duration of storage after cutting the tree [11] [12]. The microorganisms described in different studies are usually not human pathogens but the parts of the total flora of microorganisms commonly found in soil and on plants [13] [14]. Nevertheless, the presence of types of microbes determines the interrelated population diversity because of their symbiotic relations [15].

Hygienic characteristics of wood are often misunderstood because of its organic, porous and moisture absorbing surface. In fact, these properties are thanksgiving because the organic nature of wood makes it environment-friendly, the absorption potential of wood can cause desiccation conditions for microbes, and the presence of extractives can kill or inhibit harmful microorganisms [16] [17]. Such implication may allow to decrease the use of chemical agents for cleaning operations, which are a big concern regarding chemical hazard and antimicrobial resistance [18] [19]. There is a gap of knowledge to relate the antimicrobial nature of wood to its applications as a suitable hygienic surface for interior constructions.

Current review describes the major microbe inhibiting physicochemical strategies of untreated wood material. It summarizes the antimicrobial mechanism of wood involving porous structure, moisture content and chemical profile. It does not include the treated wood surfaces for the phytosanitary and esthetic purposes that may interfere with the natural properties of wooden surfaces [20] [21] and also cause chemical hazards to the environment and public health [19].

\section{Porous Structure: Does It Support Microbial Growth?}

Wood is a complex porous material which has specific arrangement of lignocellulose walls cells in parallel and perpendicular directions. Such arrangements leave open spaces on surface in form of pores. The size, frequency and arrangement of pores vary in different species of wood. According to the size of the pore, they are classified into three categories: micropores $(80-1.8 \mathrm{~nm})$, mesopores (500 - $80 \mathrm{~nm}$ ) and macropores (radius $58-2 \mu \mathrm{m}$ and $2-0.5 \mu \mathrm{m}$ ) [22]. It is generally regarded that these tiny holes retain microbes and make the cleaning difficult because of the probability that bacteria meets disinfectant is very weak. Ultimately, the wood surfaces are considered to be more contaminated than 
other, non-porous surfaces [21] [23]. It is true that wood surface retains bacteria but it does not strictly mean that bacteria are then, necessarily, transferred to something which is in contact with wood [24]. For instance, for Soares et al., 2012, the wood pine absorbs inoculum more rapidly as compared to other smooth materials [25] and the difficulty to recover microbes from wood surfaces means that these organisms are stuck inside wood structures [26]. Thus, it can be assumed that these bacteria do not contaminate the contact objects like food or hands [3] [5] [27]. This phenomenon was confirmed by Vainio-Kaila et al. [28], who observed that Colony Forming Units (CFUs) of Escherichia coli and Listeria monocytogenes not only decreased faster on pine heartwood as compared to glass surface but also did not increase on the next day, which excluded the possibility that microbial recovery was less because of bacteria hidden in the wood and stay viable.

The porosity helps in the drying process of wood, contrarily, non-porous materials take longer time to get dry [29]. For example, Chiu et al. [30] compared bamboo plant and wood which were considered as rough and porous material, with plastic, stainless steel, and glazed ceramic tile which were apparently considered as smooth and less porous material. Vibrio parahaemolyticus seemed to survive better on smooth surfaces as compared to porous material, probably because smooth surfaces could maintain higher surface moisture conditions for longer time [31].

Porosity of wood material varies in different planes of cutting [32]. Furthermore, the presence of more pores means more exposure of extractives from cut cells and deeper retention of bacteria inside the wood. Prechter et al. [33] studied the penetration depth of $E$. coli and spores of $B$. subtilis in wooden cutting boards in longitudinal and transversal directions. They observed that bacteria and spores could enter deeper (around $3 \mathrm{~mm}$ ) in transversal cuttings than in longitudinal cut woods, thus, probably posing lesser threat of recontamination with higher number of microbes. Moreover, the wood better utilizes the antimicrobial potential of extractives in transversal direction [6]. In contrast, the longitudinal cut boards of wood were easier to clean because of shallow and wider openings on surface [34].

Contrarily, the porosity not only offers difficulties in microbial recovery but may also provide shelter to some of them. The study of Boucher et al. [32] reported that the Campylobacter jejuni cells, when stressed by aeration of the liquid culture medium, were protected from death when a block of beech wood was present in the broth. They didn't observe any protective effect by using wood chemicals (free radical scavengers) or sawdust which means access to physical structure of wood, to be precise sufficiently small pores (around $16 \mu \mathrm{m}$ ) and at least $4 \mathrm{~mm}$ thickness, was necessary for the protection of cells. Interestingly, the deeply scored plastic blocks did not enhance the survival of cells in aerated broths. In this case, wooden pieces were kept in broth, which eliminates the possibility of desiccation effect owing to porosity that may have resulted in survival 
of bacteria on wood.

\section{Do the Hygroscopicity and Capillary Action Dry out the Bacteria?}

The hygroscopicity of wood is the property of taking moisture from environment. It is mostly influenced by relative humidity and temperature of environment [35]. The free water, bound water and fiber saturation point, determine the shrinkage and swelling of wood [36]. The porous structure and hygroscopic characteristics of wood lead to desiccation of bacteria [2]. Most bacteria are desiccation-sensitive and require a water potential of $-2.8 \mathrm{MPa}$ or less for growth in wood [16] [17]. It is significantly above the moisture content of air-dried wood stored indoors [37], so that properly dried wood does not offer enough water for microbial growth and multiplication [38] [39].

The hygroscopicity of wood leads to faster absorption of moisture as compared to other non-porous contact surfaces, therefore, the microbes survive longer on smooth and non-absorptive surfaces such as metal and plastics [30] [40]. Coughenour, [41] observed that Methicillin-Resistant Staphylococcus aureus (MRSA) survived longer on plastic, vinyl, flannel cloth and glass as compared to wood surface. In another study, the turkey coryza agent survived for shortest period on wood as compared to aluminum, glass, dust and feces [42].

Once the fiber saturation point is reached the wood does not absorb more moisture, therefore the hygroscopic antimicrobial potential may decrease [43]. Gehrig et al. [29] studied the survival of E. coli on wood and polyethylene by comparing Colony Forming Unit after manual and machine washing of these surfaces and 15 hours of storage at room temperature. It was observed that both wood and polyethylene showed very high numbers of bacteria in high moisture conditions. However, bacterial number was lower on wood in drier environment. This effect was attributed to the faster drying potential of wood, particularly the drainage capacity, as compared to polyethylene surface. If wood surfaces are exposed to external weathering conditions, especially, abundant rain and humidity levels, the passive effect of wood against microbes may decrease. Williams et al. [44] observed that the E. coli $\mathrm{O} 157$ persisted greater on wood than on galvanized steel, on the common farmyard surfaces, for a considerable length of time, under high moisture environmental conditions.

\section{Microbial Adherence and Biofilm Formation on Wood Surface}

The adherence of microbes to substrate is a complex phenomenon and it is the first step to biofilm formation [45]. This bonding is carried out by van der Waals, electrostatic and acid-base interactions, which depend on the physicochemical properties of the microbe and substrate, especially hydrophobicity, surface charge, and electron donor-electron acceptor properties [46]. Wood can 
serve as support material for biofilm formation of such microbes which use cellulose as nutrition for survival [47]. However, hygienically important microbes can show different results regarding their adhesion.

Dantas et al. [48] performed an experiment of microbial transfer of 10 biofilm forming $S$. enteriditis strains from chicken meat to cucumber via glass, plastic and wood cutting boards. The formation of biofilm was highest on wood $(60 \%)$, followed by plastic (40\%) and glass (10\%). Once the biofilm was formed, they are difficult to clean and disinfect on surfaces, and the microbial transfer from cutting boards to cucumbers was also highest in wood. However, in cheese making process, the presence of lactic acid bacteria counters the adherence of many pathogens including Listeria spp., Salmonella and other enterobacteriaceae [49] [50].

The presence of biofilms from natural wood flora may stop the growth of some harmful organisms. Therefore, this factor should be considered for microbial safety in hygienic surfaces, such as cheese ripening wooden boards and biocontrol for nosocomial pathogens in hospital environment [51]-[58]. Mariani et al. [59] tested the fate of two L. monocytogenes strains, over time as a function of the presence of a native biofilm, the farmhouse origin of cheeses, and the wooden shelves properties. In presence of a native microbial flora on the shelves, deposited populations of $L$. monocytogenes remained stable or even decreased by up to $2 \log 10\left(\mathrm{CFU} / \mathrm{cm}^{2}\right)$ after 12 days of incubation at $15^{\circ} \mathrm{C}$ in all tested conditions. By contrast, L. monocytogenes populations increased by up to $4 \log 10$ $\left(\mathrm{CFU} / \mathrm{cm}^{2}\right)$ when the resident biofilm was thermally inactivated, suggesting a microbial origin of the observed inhibitory effect. In a similar study no inhibitory compounds by biofilm microflora were observed [49]. Therefore this reduction in L. monocytogenes numbers can be attributed to "Jameson effect" according to the nutrient consumption and exhaustion by competitive microorganisms [49] [60] [61]. This type of effect can be used on wood for treatment with probiotic type microorganisms and their bio-surfactants, which may antagonize the growth of nosocomial pathogens on inanimate surfaces [62].

\section{Hygienic Suitability of Aged Wood Surface}

Wood is an organic material which undergoes changes in its structure and properties along the time under different use and weathering conditions [63]. It is anticipated that rough and cracked wood surface can entrap bacteria which may help in survival of these organisms ultimately posing a risk to contact persons [23] [64]. However, studies have shown that the weathering conditions affect other materials too and scored wood surfaces has been seen to perform better than other in use scored surfaces like plastic, regarding the survival of microbes. The electron microscopy reveals that the cuts on wood surface open in the drying process and therefore bacteria cannot survive and cleaning also becomes easier [29], at least not more difficult as compare to plastic [65] [66]. Meanwhile, under similar circumstances, the plastic surface cuts have closing 
structure which can provide shelter for microbial survival [29]. Koch et al. [20] also reported that artificially aged plastic surface supported more bacterial survival as compared to wood.

Apart from structural composition, the chemical constituents also do not change as rapidly as they are perceived. For example, in case of wooden shelves being used in cheese making, the age does not have significant impact on water activity, $\mathrm{pH}$, and salt concentration, and neither on major microflora, such as, Leuconostoc sp., facultative heterofermentative Lactobacilli, Staphylococci, Enterococci and Pseudomonads [67].

The aging of materials also bring the wearing and tearing of surfaces which provide different conditions of survival to microbes as compared to new or unused surfaces. Gough and Dodd, [68] assessed the survival of Salmonella Typhimurium persistence on food preparation surfaces, wood and plastic chopping boards both new and after heavy scoring. Survival was assessed by counting the numbers of $S$. Typhimurium recovered after rinsing the inoculum off the board surface followed by contact plates. Recovery of the board inoculum from the rinse diluent was significantly greater from plastic than wood, and from untreated than scored boards. However, the disinfection was more readily carried out on plastic than both types of wood boards.

As previously described, wood has extractives which may act as antimicrobial agents. These chemical agents may degrade by some treatments, especially, high temperature processing of wood and also by washing by different liquids which may act as solvents for these chemicals and the quantities may decrease in cleaning process [69]. However, such washing and aging do not decrease the overall hygienic nature of wood material [49].

\section{Contact Time and Contamination Rate from Wood Surfaces}

Wood absorbs moisture and liquid microbial inoculum rapidly compared to non-absorptive materials, leading to lower recovery concentration on contact from wood surface, for example when touching wood with hand or preparing food on the surface. However, this absorption is different according to the type of contact between contaminated material and wood. For example, Miller et al. [70] observed that swabbing showed non-significant difference in the bacterial numbers after short contact time (0 and $90 \mathrm{~min}$ ) of placing ground beef onto plastic and hardwood cutting boards at room temperature. However, longer contact time of microbes on wood shows different results, as Revol-Junelles et al. [71] observed that E. coli cells and Bacillus cereus spores became metabolically inactive faster on dry poplar wood as compared to glass surface on room temperature with prolonged contact time, which made their viable contact recovery very low. Moore et al. [72] reported that the number of bacteria recovered from formica and stainless steel were not only higher than polypropylene or wood, but also, regardless of application medium or holding time, the transfer to the 
model food was also high.

On the other hand, the transfer of microbes from wood surfaces to the contact medium may depend upon contact time, which means a longer contact time is generally linked to higher microbial contaminant/transfer to contact medium [73]. For example, Dawson et al. [74] reported that transfer rates of Salmonella typhimurium from carpet, tile and wood to bologna rose with increase in brief contact time of 5, 30 and $60 \mathrm{~s}$. However, for longer contact time the transfer rate may be lesser because of antimicrobial role of wood, for example, Mohammad and Al-Taee (2014) observed that the transferrable quantities of E. coli and Salmonella spp. after 5 and 15 minutes from surface to meat and vegetables were higher on glass, plastic and steel as compared to wood [75]. Montibus et al. (2016) studied the transfer rate of Penicillium expansum from poplar crates and plastic surfaces to apples during the study period of one week. They observed that the transfer rate continued to decrease on wood surface during the study period while it was constant or increasing from plastic [5].

Goh et al. [76] performed an experiment regarding the contact transfer of $L$. monocytogenes from wooden and plastic cutting boards to the uncooked and cooked meat. For this study, the chicken meat was contaminated with $200 \mu \mathrm{l}$ solution at $7 \log 10 \mathrm{CFU} / \mathrm{ml}$ of bacteria and contacted with test surfaces for $5 \mathrm{~s}$. Later, the cooked and uncooked chicken was contacted on contaminated surfaces to determine the transfer. After $1 \mathrm{~h}$ of holding time, the transfer of microbes from meat to wood (6\%) and wood to meat (11\% and $0 \%)$ was lower than that of plastic ( $71.8 \%$ and $25 \%$ respectively).

\section{Are Wood Surfaces Difficult to Clean?}

As a misconception, the absorbance potential and porous nature of wood is generally considered as a hindrance in cleaning process. However, many studies have shown that wood surfaces are not more difficult to clean as compared to other non-porous surfaces [66] [77] [78]. Even, the ordinary washing of wood and plastic preparation surfaces in the kitchen gives the satisfactory results regarding the elimination of hygienically important microbes from these surfaces [20]. Ak et al. [69] observed that lesser viable E. coli, L. innocua, L. monocytogenes and Salmonella bacteria were recovered from 9 types of wooden cutting boards as compared to plastic boards. Moreover, the cleaning with hot water and detergent eliminated these microbes on all cutting boards [78], which is contrary to the assumption that wood is difficult to clean.

Zangerl et al. [69] examined the effect of cleaning and heat disinfection processes of 1 year old spruce fir wooden shelves used for cheese ripening on the survival of $L$. monocytogenes. The cut boards were inoculated with a suspension containing $5.5 \times 10^{7} \mathrm{CFU} / \mathrm{ml}$ of $L$. monocytogenes and incubated for $24 \mathrm{~h}$ at room temperature, the boards were cleaned by soaking them for $15 \mathrm{~min}$ in a solution of hot alkaline detergent followed by brushing and rinsing with warm 
water. Some of the cleaned boards were subsequently heat treated at $80^{\circ} \mathrm{C}$ for $5 \mathrm{~min}$ and at $65^{\circ} \mathrm{C}$ for $15 \mathrm{~min}$, respectively. The cleaning procedure alone was not sufficient to render $L$. monocytogenes from the upper $2 \mathrm{~mm}$ wood layer inactive. In the case of both temperature-time combinations for heat disinfection, however, L. monocytogenes was not detectable. It was concluded that the use of wooden shelves does not affect the hygienic safety of cheeses if such shelves are in good repair and are thoroughly cleaned and sanitized by heat treatment. Therefore, there is no reason to replace wood employed in cheese ripening processes with other materials. In another study, it has been reported that the steam treatment of spruce fir wood for $20 \mathrm{~min}$ with three different temperature programs between $70^{\circ} \mathrm{C}$ and $78^{\circ} \mathrm{C}$, made the L. monocytogenes undetectable when tested at 7,8 and 9 days [79].

Sometimes wood surfaces may take little bit longer cleaning time depending upon type of disinfection or cleaning method use. Deza et al. [80] submerged the pieces of pine-wood and plastic cutting boards in the 9 to $10 \log \mathrm{CFU} / \mathrm{ml}$ solution of E. coli, L. monocytogenes, $P$. aeruginosa, and $S$. aureus and then dried the boards under laminar flow for 20 minutes. Later, these inoculated pieces were immersed in the disinfectant solutions of sodium hypochlorite $(\mathrm{NaClO})$, acidic electrolyzed water and neutral electrolyzed water. They found that all the solutions decreased the microbial count to undetectable limit plastic after $1 \mathrm{mi}-$ nutes of submersion while in case of wood they there were live cells present after 1 minute of treatment which became inactive after 5 minutes of treatment. DeVere and Purchase, [81] reported the survival of E. coli and S. aureus on four different surfaces cleaned with four types of cleaning agents including wipes and sprays. The microbial solution was inoculated on all surfaces and dried for 30, 60 and $120 \mathrm{~min}$ before being cleaned with antibacterial products. The results showed that wood was more efficiently cleaned with all types of products as compared to glass, plastic and antibacterial plastic surfaces. Lücke and Skowyrs$\mathrm{ka},[66]$ also reported that after proper cleaning, the microbial counts were same on polyethylene, maple and beech cutting boards, suggesting that the wood material is not worse in cleanability than commonly used plastic.

Campylobacter may survive in presence of wood [32], however, the cleaning methods can remove this hurdle. Acuff et al. [82] reported that washing of wooden utensils with detergent on dishwasher removed the Campylobacter jeju$n i$, while hand washing did not. Therefore, attention should be given while dealing with Campylobacter contaminated food products on wooden surfaces. Thormar and Hilmarsson [83] observed that the viable Campylobacter counts were reduced below the detectable level on plastic and wooden board surfaces after treatment with monocaprin emulsions for 2 min. Al-Qadiri et al. [84] reported that C. jejuni, Salmonella Typhimurium, E. coli O157:H7, L. monocytogenes and $S$. aureus were significantly reduced both on wooden and plastic cutting boards after 1 to 5 minutes of treatment with neutral electrolyzed water, quaternary ammonium, and lactic acid-based solutions. 


\section{Do the Species and Part of Wood Have Role in Antimicrobial Behavior?}

Every wood species have unique anatomy and chemistry which leads to specific action against microbes [35] [85]. The studies have shown these variations of antimicrobial properties of wood as shown in Table 1. Johnston et al. [86] tested the antimicrobial activities of essential oils extracted from the wood of Alaska cedar (Chamaecyparis nootkatensis), western juniper (Juniperus occidentalis) and Douglas fir (Pseudotsuga menziesii), as well as, methanol extracts of ponderosa pine (Pinus ponderosa) and western red cedar (Thuja plicata) against Clostridium perfringens, Fusobacterium necrophorum, Candida albicans and Actinomyces bovis, which are common cause of multiple infections in farm animals. The extracts of western juniper and Alaska cedar exhibited strong growth inhibitory activities against all tested pathogens while of the Douglas fir showed activity only against $A$. bovis. Regarding the level of beneficial lactic acid bacteria on wooden vats used in dairy processing, Cruciata et al. [49] reported that the level of these microbes varied depending on the type of wood species being used. For instance, the high levels were registered on the surfaces of cedar, ash, walnut and poplar vats. Within this bacterial group, enterococci were only detected on cedar and cherry woods.

Wood is a complex material having different structural and chemical composition from different parts of a tree. The studies have shown that the extractives from bark, heartwood and sapwood have different effect on microbes [4] [86] [90] [91].

\section{Biochemical Profile of Wood: Antimicrobial and Safety Perspective}

The wood contains many types of extractives that principally protect it against the microbial, fungal and insect degradation. The antimicrobial chemicals include tannins, phenolic acids, flavenoids and terpenoids [92]. The mode of action of different wood chemicals can be seen in Table 2 .

The emissions from wood do not pose health risks to inhabitants and they do not reduce the antimicrobial properties of material. The wood is always stored and dried before use. That allowed the volatile organic compounds to emit until stable level. Moreover, the age and storage time of pine wood did not influence its antimicrobial behavior [87].

The antimicrobial chemicals from wood can also be questioned for their transfer to contact subjects like food [43]. However, there are no specific studies showing such migration of chemicals, causing harmful effects regarding spoilage of food or human health [93]. In fact, the migration of chemicals from wood to contact subjects is very low [94].

The $\mathrm{pH}$ of wood is generally acidic due to its chemical composition and this property also helps to stop the surface adhesion and survival of certain bacteria including Clostridia, Staphylococci, E. coli, L. monocytogenes, Pseudomonas spp., and Salmonella spp. [49] [53] [95]. 
Table 1. Ranking of wood species depending upon the hygienic suitability.

\begin{tabular}{|c|c|c|}
\hline Reference & Bacteria & Ranking \\
\hline$[4]$ & $\begin{array}{l}\text { Staphylococcus aureus, Pseudomonas } \\
\text { aeruginosa, Enterobacter faecium, } \\
\text { and } B . \text { subtilis }\end{array}$ & Pine $>$ larch \\
\hline [17] & E. coli and E. faecium & $\begin{array}{l}\text { Pine }=\text { oak }=\text { larch }>\text { maple }>\text { spruce }>\text { beech }> \\
\text { poplar } \\
\text { Pine }=\text { oak }>\text { larch }=\text { maple }=\text { spruce }=\text { beech } \\
=\text { poplar }\end{array}$ \\
\hline [20] & $\begin{array}{l}\text { Bacillus subtilis and Pseudomonas } \\
\text { fluorescens }\end{array}$ & Oak $>$ spruce \\
\hline [38] & Poultry manure flora & Pine $>$ larch $=$ maple \\
\hline [70] & E. coli $0157: \mathrm{H} 7$ & White ash $>$ red oak $>$ black cherry $>$ maple \\
\hline [87] & Escherichia coli and E. faecium & Pine $>$ poplar $=$ beech \\
\hline [88] & $\begin{array}{l}\text { S. aureus, } P \text {. aeruginosa, and } \\
\text { Acinetobacter baumannii }\end{array}$ & Oak $>$ Douglas fir $=$ pine $>$ poplar \\
\hline $\begin{array}{c}{[89][90]} \\
{[91]}\end{array}$ & $\begin{array}{l}\text { S. aureus, E. coli, Enterococcus faecalis, } \\
\text { Streptococcus pneumoniae }\end{array}$ & Pine $>$ spruce \\
\hline
\end{tabular}

Table 2. Antimicrobial actions of wood chemicals against microbes*.

\begin{tabular}{cc}
\hline Target & Wood chemicals \\
\hline Cell wall and cell membrane & $\begin{array}{c}\text { Flavonoids, tannins, aldehydes, phenolic acids, } \\
\text { terpenoids, alkaloids, terpenes } \\
\text { Fucleic acid }\end{array}$ \\
Metals metabolism & Tannins \\
Protein synthesis & Aldehydes, tannins \\
Energy metabolism & Flavonoids, phenolic acids \\
Adhesion and Biofilm formation & Phenolic acids, quinones
\end{tabular}

*the data is adapted from[92] [96] [97] [98].

As Table 2 shows, many of wood metabolites effect on microbial cell wall and cell membrane, the difference of membrane structure among different types of microorganisms may give them support or vulnerability to this antimicrobial effect [99]. For example, the Gram negative bacteria, E. coli, survives lesser on wood as compared to Gram positive, E. faecium, isolates [87]. However, the extractive action of wood is stronger against multiple Gram positive microbes ( $S$. aureus and E. faecium) as compared to gram negative bacteria (E. coli) [4] [89], which shows that probably, the physical microbial effect of wood is stronger against Gram negative, while chemical effect is stronger against Gram positive bacteria. It might be because the Gram positive bacteria have thicker cell wall which might provide them shield against the desiccation effect of wood. Unlike Gram negative bacteria, the Gram positive bacteria lack the outer membrane containing lipopolysaccharide [99] [100], which may render them prone to chemical action of wood metabolites. Further research is needed to justify the difference of survival of different microbes on similar wood types. 


\section{Conclusions}

The recent studies have developed our understanding regarding the natural hygienic properties of wood. Laboratory and field trials have shown a reduction in microbial counts on wood contact surfaces, indicating their importance as promising additional support to the hygienic measures to curb the number and severity of contamination/infections in healthcare and food industries.

Different species, parts, and age of wood have different action against type, intensity, and frequency of contact of microbes. Therefore, specialized studies are needed to establish the standard values to address these parameters that would be helpful in determining the most cost-effective way to optimize the safety of contact surfaces.

As the safety authorities around the globe are more focused on prevention than reaction, they have implemented the concept of environmental monitoring of hygienically sensitive places. For example, Food Safety Modernization Act in USA and some organizational repositories in European Union enforce the environmental surveillance as part of safety program. In this scenario, the antimicrobial properties of wood should be kept in mind while implementing an environmental hygiene program.

\section{Conflicts of Interest}

The authors declare no conflicts of interest regarding the publication of this paper.

\section{References}

[1] Schuster, A. (2006) Wie hygienisch und sinnvoll ist Holz in Patientenzimmern? Krankenhaushygiene Infektionsverhütung, 28, 131.

[2] Aviat, F., Gerhards, C., Rodriguez-Jerez, J., Michel, V., Bayon, I.L., Ismail, R. and Federighi, M. (2016) Microbial Safety of Wood in Contact with Food: A Review. Comprehensive Reviews in Food Science and Food Safety, 15, 491-505. https://doi.org/10.1111/1541-4337.12199

[3] Ismail, R., Aviat, F., Gay-Perret, P., Le Bayon, I., Federighi, M. and Michel, V. (2017) An Assessment of L. monocytogenes Transfer from Wooden Ripening Shelves to Cheeses: Comparison with Glass and Plastic Surfaces. Food Control, 73, 273-280. https://doi.org/10.1016/j.foodcont.2016.08.014

[4] Laireiter, C.M., Schnabel, T., Köck, A., Stalzer, P., Petutschnigg, A., Oostingh, G.J. and Hell, M. (2013) Active Anti-Microbial Effects of Larch and Pine Wood on Four Bacterial Strains. BioResources, 9, 273-281. https://doi.org/10.15376/biores.9.1.273-281

[5] Montibus, M., Ismaill, R., Michel, V., Federighi, M., Aviat, F. and Le Bayon, I. (2016) Assessment of Penicillium expansum and Escherichia coli Transfer from Poplar Crates to Apples. Food Control, 60, 95-102. https://doi.org/10.1016/j.foodcont.2015.07.025

[6] Pailhoriès, H., Munir, M.T., Aviat, F., Federighi, M., Belloncle, C. and Eveillard, M. (2017) Oak in Hospitals, the Worst Enemy of Staphylococcus aureus? Infection Control \& Hospital Epidemiology, 38, 382-384.

https://doi.org/10.1017/ice.2016.304 
[7] Tiwari, A., Patnayak, D.P., Chander, Y., Parsad, M. and Goyal, S.M. (2006) Survival of Two Avian Respiratory Viruses on Porous and Nonporous Surfaces. Avian Diseases, 50, 284-287. https://doi.org/10.1637/7453-101205R.1

[8] Burnard, M.D. and Kutnar, A. (2015) Wood and Human Stress in the Built Indoor Environment: A Review. Wood Science and Technology, 49, 969-986.

https://doi.org/10.1007/s00226-015-0747-3

[9] Demattè, M.L., Zucco, G.M., Roncato, S., Gatto, P., Paulon, E., Cavalli, R. and Zanetti, M. (2018) New Insights into the Psychological Dimension of Wood-Human Interaction. European Journal of Wood and Wood Products, 76, 1093-1100. https://doi.org/10.1007/s00107-018-1315-y

[10] Nyrud, A.Q. and Bringslimark, T. (2010) Is Interior Wood Use Psychologically Beneficial? A Review of Psychological Responses toward Wood. Wood and Fiber Science, 42, 202-218.

[11] Beyer, G., Arason, S. and Gudbjornsdottir, B. (2002) Wood in Food-Hygienic Properties of Wood-Field Studies on Wooden Pallets and Wood in Construction. Icelandic Fisheries Laboratories. Nordic Industrial Fund, Sweden.

[12] Dutkiewicz, J., Sorenson, W.G., Lewis, D.M. and Olenchock, S.A. (1992) Levels of Bacteria, Fungi and Endotoxin in Stored Timber. International Biodeterioration \& Biodegradation, 30, 29-46. https://doi.org/10.1016/0964-8305(92)90022-G

[13] Cosenza, B.J., McCreary, M., Buck, J.D. and Shigo, A.L. (1970) Bacteria Associated with Discolored and Decayed Tissues in Beech, Birch, and Maple. Phytopathology, 60, 1547. https://doi.org/10.1094/Phyto-60-1547

[14] Munir, M.T., Munir, A.R., ul Hasan, M. and Abubakar, M. (2014) Epidemiology and Management Strategies of Johne's Disease in Endemic Situations. Research Journal for Veterinary Practitioners, 2, 84-90. https://doi.org/10.14737/journal.rjvp/2014/2.5.84.90

[15] Johnston, S.R., Boddy, L. and Weightman, A.J. (2016) Bacteria in Decomposing Wood and Their Interactions with Wood-Decay Fungi. FEMS Microbiology Ecology, 92, 1-12. https://doi.org/10.1093/femsec/fiw179

[16] Alpert, P. (2006) Constraints of Tolerance: Why Are Desiccation-Tolerant Organisms So Small or Rare? Journal of Experimental Biology, 209, 1575-1584. https://doi.org/10.1242/jeb.02179

[17] Milling, A., Kehr, R., Wulf, A. and Smalla, K. (2005) Survival of Bacteria on Wood and Plastic Particles: Dependence on Wood Species and Environmental Conditions. Holzforschung, 59, 72-81. https://doi.org/10.1515/HF.2005.012

[18] Fahimipour, A.K., Mamaar, S.B., McFarland, A.G., Blaustein, R.A., Chen, J., Glawe, A.J., Kline, J., Green, J.L., Halden, R.U., Wymelenberg, K.V.D., Huttenhower, C. and Hartmann, E.M. (2018) Antimicrobial Chemicals Associate with Microbial Function and Antibiotic Resistance Indoors. mSystems, 3, e00200-18. https://doi.org/10.1128/mSystems.00200-18

[19] Obe, T., Nannapaneni, R., Sharma, C.S. and Kiess, A. (2018) Homologous Stress Adaptation, Antibiotic Resistance, and Biofilm Forming Ability of Salmonella Enterica Serovar Heidelberg ATCC8326 on Different Food-Contact Surfaces Following Exposure to Sublethal Chlorine Concentrations. Poultry Science, 97, 951-961. https://doi.org/10.3382/ps/pex346

[20] Koch, A.P., Kofod, C.J., Konova, D., Kvist, K.E. and Lindergaard, B. (2002) Wood, Plastic and Steel-Comparason of Hygenic Properties. The Danish Technological Institute.

https://www.google.fr/url?sa=t\&rct=j\&q=\&esrc=s\&source=web\&cd=22\&cad=rja\&u 
act=8\&ved=0ahUKEwiSsp_T4uvNAhWD0xoKHbDMDXE4FBAWCCIwAQ\&url= http\%3A\%2F\%2Fwww.teknologisk.dk\%2F_\%2Fmedia\%2FWood_in_the_Food_Ind us-

try_Report_10.pdf\&usg=AFQjCNEU8nP4_jYUX21Bk8TV2G2WNNfQfA\&sig2=O oaFstRRAnpnEtEoppxEvg\&bvm=bv.126130881,d.d2s

[21] Abrishami, S.H., Tall, B.D., Bruursema, T.J., Epstein, P.S. and Shah, D.B. (1994) Bacterial Adherence and Viability on Cutting Board Surfaces. Journal of Food Safety, 14, 153-172. https://doi.org/10.1111/j.1745-4565.1994.tb00591.x

[22] Plötze, M. and Niemz, P. (2011) Porosity and Pore Size Distribution of Different Wood Types as Determined by Mercury Intrusion Porosimetry. European Journal of Wood and Wood Products, 69, 649-657. https://doi.org/10.1007/s00107-010-0504-0

[23] Gilbert, R.J. and Watson, H.M. (1971) Some Laboratory Experiments on Various Meat Preparation Surfaces with Regard to Surface Contamination and Cleaning. International Journal of Food Science \& Technology, 6, 163-170. https://doi.org/10.1111/j.1365-2621.1971.tb01604.x

[24] Ismaill, R., Bayon, I.L., Michel, V., Jequel, M., Kutnik, M., Aviat, F. and Fédérighi, M. (2015) Comparative Study of Three Methods for Recovering Microorganisms from Wooden Surfaces in the Food Industry. Food Analytical Methods, 8, 1238-1247. https://doi.org/10.1007/s12161-014-0008-3

[25] Soares, V.M., Pereira, J.G., Viana, C., Izidoro, T.B., Bersot, L. dos S. and Pinto, J.P. de A.N. (2012) Transfer of Salmonella Enteritidis to Four Types of Surfaces after Cleaning Procedures and Cross-Contamination to Tomatoes. Food Microbiology, 30, 453-456. https://doi.org/10.1016/j.fm.2011.12.028

[26] Cliver, D.O. (2006) Cutting Boards in Salmonella Cross-Contamination. Journal of AOAC International, 89, 538-542.

[27] Carpentier, B. (1997) Sanitary Quality of Meat Chopping Board Surfaces: A Bibliographical Study. Food Microbiology, 14, 31-37. https://doi.org/10.1006/fmic.1996.0061

[28] Vainio-Kaila, T., Kyyhkynen, A., Viitaniemi, P. and Siitonen, A. (2011) Pine Heartwood and Glass Surfaces: Easy Method to Test the Fate of Bacterial Contamination. European Journal of Wood and Wood Products, 69, 391-395. https://doi.org/10.1007/s00107-010-0453-7

[29] Gehrig, M., Schnell, G., Zürcher, E. and Kucera, L.J. (2000) Hygienische Eigenschaften von Holz-und Kunststoffbrettern in der Nahrungsmittelverarbeitung und-präsentation: Ein Vergleich. Holz als Roh-und Werkstoff, 58, 265-269. https://doi.org/10.1007/s001070050423

[30] Chiu, T.-H., Duan, J., Liu, C. and Su, Y.-C. (2006) Efficacy of Electrolysed Oxidizing Water in Inactivating Vibrio Parahaemolyticus on Kitchen Cutting Boards and Food Contact Surfaces. Letters in Applied Microbiology, 43, 666-672. https://doi.org/10.1111/j.1472-765X.2006.02006.x

[31] Shi, Y., Sun, R., An, D., Lu, W., Zhang, C., Wang, L., Liu, Y. and Wang, Q. (2017) Mathematical Quantification of Inactivation of Vibrio Parahaemolyticus on Two Types of Surface Soiled with Different Substrates. Food Control, 74, 1-8. https://doi.org/10.1016/j.foodcont.2016.11.025

[32] Boucher, S.N., Chamberlain, A.H.L. and Adams, M.R. (1998) Enhanced Survival of Campylobacter Jejuni in Association with Wood. Journal of Food Protection, 61, 26-30. https://doi.org/10.4315/0362-028X-61.1.26

[33] Prechter, S., Betz, M., Cerny, G., Wegener, G. and Windeisen, E. (2002) Hygie- 
nische Aspekte von Schneidebrettern aus Holz bzw. Kunststoff. Holz als Roh-und Werkstoff, 60, 239-248. https://doi.org/10.1007/s00107-002-0301-5

[34] Dubreil, L., Aviat, F., Anthoine, V., Ismail, R., Rossero, A. and Federighi, M. (2018) Confocal Spectral Microscopy-An Innovative Tool for Tracking of Pathogen Agents on Contaminated Wooden Surfaces. European Journal of Wood and Wood Products, 76, 1083-1085. https://doi.org/10.1007/s00107-018-1294-Z

[35] Munir, M.T., Belloncle, C., Irle, M. and Federighi, M. (2019) Wood-Based Bedding in Poultry Production: A Review. World s Poultry Science Journal, 75.

[36] Ramananantoandro, T., Eyma, F., Belloncle, C., Rincé, S. and Irle, M. (2018) Effects of Machining Parameters on Raised Grain Occurring after the Application of Water-Based Finishes. European Journal of Wood and Wood Products, 76, 1323-1333. https://doi.org/10.1007/s00107-017-1250-3

[37] Thybring, E., Kymäläinen, M. and Rautkari, L. (2018) Moisture in Modified Wood and Its Relevance for Fungal Decay. iForest-Biogeosciences and Forestry, 11, 418-422. https://doi.org/10.3832/ifor2406-011

[38] Milling, A., Smalla, K. and Wulf, A. (2005) The Use of Wood in Practice-A Hygienic Risk? Holz als Roh-und Werkstoff, 63, 463-472.

https://doi.org/10.1007/s00107-005-0064-x

[39] Stienen, T., Schmidt, O. and Huckfeldt, T. (2014) Wood Decay by Indoor Basidiomycetes at Different Moisture and Temperature. Holzforschung, 68, 9-15. https://doi.org/10.1515/hf-2013-0065

[40] Xi, L., Qin, D., An, X. and Wang, G. (2013) Resistance of Natural Bamboo Fiber to Microorganisms and Factors That May Affect Such Resistance. BioResources, 8, 6501-6509. https://doi.org/10.15376/biores.8.4.6501-6509

[41] Coughenour, C. (2009) An Evaluation of Methicillin Resistant Staphylococcus Aureus Survival on Five Environmental Surfaces under Two Different Humidities, with and without the Addition of Bovine Serum Albumin. UNLV Theses, Dissertations, Professional Papers, and Capstones.

http://digitalscholarship.unlv.edu/thesesdissertations/784

[42] Cimiotti, W., Glunder, G. and Hinz, K.H. (1982) Survival of the Bacterial Turkey Coryza Agent. Veterinary Record, 110, 304-306.

https://doi.org/10.1136/vr.110.13.304

[43] Mousavi, S.M., Desobry, S. and Hardy, J. (1998) Mathematical Modelling of Migration of Volatile Compounds into Packaged Food via Package Free Space. Part II: Spherical Shaped Food. Journal of Food Engineering, 36, 473-484. https://doi.org/10.1016/S0260-8774(98)00059-4

[44] Williams, A.P., Avery, L.M., Killham, K. and Jones, D.L. (2005) Persistence of Escherichia Coli O157 on Farm Surfaces under Different Environmental Conditions. Journal of Applied Microbiology, 98, 1075-1083. https://doi.org/10.1111/j.1365-2672.2004.02530.x

[45] Tomičić, R., Tomičić, Z. and Raspor, P. (2017) Adhesion of Candida Spp. and Pichia Spp. to Wooden Surfaces. Food Technology and Biotechnology, 55, 138-142. https://doi.org/10.17113/ftb.55.01.17.4514

[46] Soumya, E., Saad, I.K., Abdellah, H. and Hassan, L. (2013) Experimental and Theoretical Investigations of the Adhesion Time of Penicillium Spores to Cedar Wood Surface. Materials Science and Engineering: C, 33, 1276-1281. https://doi.org/10.1016/j.msec.2012.12.026

[47] Asri, M., El Ghachtouli, N., Elabed, S., Ibnsouda Koraichi, S., Elabed, A., Silva, B. 
and Tavares, T. (2018) Wicherhamomyces Anomalus Biofilm Supported on Wood Husk for Chromium Wastewater Treatment. Journal of Hazardous Materials, 359, 554-562. https://doi.org/10.1016/j.jhazmat.2018.05.050

[48] Dantas, S.T.A., Rossi, B.F., Bonsaglia, E.C.R., Castilho, I.G., Hernandes, R.T., Fernandes, A. and Rall, V.L.M. (2018) Cross-Contamination and Biofilm Formation by Salmonella Enterica Serovar Enteritidis on Various Cutting Boards. Foodborne Pathogens and Disease, 15, 81-85. https://doi.org/10.1089/fpd.2017.2341

[49] Cruciata, M., Gaglio, R., Scatassa, M.L., Sala, G., Cardamone, C., Palmeri, M., Moschetti, G., Mantia, T.L. and Settanni, L. (2018) Formation and Characterization of Early Bacterial Biofilms on Different Wood Typologies Applied in Dairy Production. Applied and Environmental Microbiology, 84, e02107-17.

[50] Galinari, É., da Nóbrega, J.E., de Andrade, N.J. and de Luces Fortes Ferreira, C.L. (2014) Microbiological Aspects of the Biofilm on Wooden Utensils Used to Make a Brazilian Artisanal Cheese. Brazilian Journal of Microbiology, 45, 713-720. https://doi.org/10.1590/S1517-83822014000200047

[51] Di Grigoli, A., Francesca, N., Gaglio, R., Guarrasi, V., Moschetti, M., Scatassa, M.L., Settanni, L. and Bonanno, A. (2015) The Influence of the Wooden Equipment Employed for Cheese Manufacture on the Characteristics of a Traditional Stretched Cheese during Ripening. Food Microbiology, 46, 81-91.

https://doi.org/10.1016/j.fm.2014.07.008

[52] Didienne, R., Defargues, C., Callon, C., Meylheuc, T., Hulin, S. and Montel, M.-C. (2012) Characteristics of Microbial Biofilm on Wooden Vats ("Gerles") in PDO Salers Cheese. International Journal of Food Microbiology, 156, 91-101. https://doi.org/10.1016/j.ijfoodmicro.2012.03.007

[53] Gaglio, R., Cruciata, M., Gerlando, R.D., Scatassa, M.L., Cardamone, C., Mancuso, I., Sardina, M.T., Moschetti, G., Portolano, B. and Settanni, L. (2015) Microbial Activation of Wooden Vats Used for Traditional Cheese Production and Evolution of the Neo-Formed Biofilms. Applied and Environmental Microbiology, AEM.02868-15.

[54] Licitra, G., Caccamo, M., Valence, F. and Lortal, S. (2017) Traditional Wooden Equipment Used for Cheesemaking and Their Effect on Quality. Global Cheesemaking Technology, Wiley-Blackwell, Hoboken, 157-172. https://doi.org/10.1002/9781119046165.ch0g

[55] Lortal, S., Di Blasi, A., Madec, M.-N., Pediliggieri, C., Tuminello, L., Tanguy, G., Fauquant, J., Lecuona, Y., Campo, P., Carpino, S. and Licitra, G. (2009) Tina Wooden Vat Biofilm: A Safe and Highly Efficient Lactic Acid Bacteria Delivering System in PDO Ragusano Cheese Making. International Journal of Food Microbiology, 132, 1-8. https://doi.org/10.1016/j.ijfoodmicro.2009.02.026

[56] Lortal, S., Licitra, G. and Valence, F. (2014) Wooden Tools: Reservoirs of Microbial Biodiversity in Traditional Cheesemaking. Microbiology Spectrum, 2, CM-0008-2012. https://doi.org/10.1128/microbiolspec.CM-0008-2012

[57] Scatassa, M.L., Gaglio, R., Macaluso, G., Francesca, N., Randazzo, W., Cardamone, C., Di Grigoli, A., Moschetti, G. and Settanni, L. (2015) Transfer, Composition and Technological Characterization of the Lactic Acid Bacterial Populations of the Wooden Vats Used to Produce Traditional Stretched Cheeses. Food Microbiology, 52, 31-41. https://doi.org/10.1016/j.fm.2015.06.008

[58] Settanni, L., Di Grigoli, A., Tornambé, G., Bellina, V., Francesca, N., Moschetti, G. and Bonanno, A. (2012) Persistence of Wild Streptococcus Thermophilus Strains on Wooden Vat and during the Manufacture of a Traditional Caciocavallo Type Cheese. International Journal of Food Microbiology, 155, 73-81. 
https://doi.org/10.1016/j.ijfoodmicro.2012.01.022

[59] Mariani, C., Oulahal, N., Chamba, J.-F., Dubois-Brissonnet, F., Notz, E. and Briandet, R. (2011) Inhibition of Listeria monocytogenes by Resident Biofilms Present on Wooden Shelves Used for Cheese Ripening. Food Control, 22, 1357-1362. https://doi.org/10.1016/j.foodcont.2011.02.012

[60] Guillier, L., Stahl, V., Hezard, B., Notz, E. and Briandet, R. (2008) Modelling the Competitive Growth between Listeria monocytogenes and Biofilm Microflora of Smear Cheese Wooden Shelves. International Journal of Food Microbiology, 128, 51-57. https://doi.org/10.1016/j.ijfoodmicro.2008.06.028

[61] Ye, K., Liu, J., Liu, M., Huang, Y., Wang, K. and Zhou, G. (2018) Effects of Two Weissella viridescens Strains on Listeria monocytogenes Growth at Different Initial Inoculum Proportions. CyTA-Journal of Food, 16, 299-305. https://doi.org/10.1080/19476337.2017.1401667

[62] Vandini, A., Temmerman, R., Frabetti, A., Caselli, E., Antonioli, P., Balboni, P.G., Platano, D., Branchini, A. and Mazzacane, S. (2014) Hard Surface Biocontrol in Hospitals Using Microbial-Based Cleaning Products. PLoS ONE, 9, e108598. https://doi.org/10.1371/journal.pone.0108598

[63] Buchner, J., Irle, M., Belloncle, C., Michaud, F. and Macchioni, N. (2018) Fungal and Bacterial Colonies Growing on Weathered Wood Surfaces. Wood Material Science \& Engineering, 14, 1-9.

[64] Welker, C., Faiola, N., Davis, S., Maffatore, I. and Batt, C.A. (1997) Bacterial Retention and Cleanability of Plastic and Wood Cutting Boards with Commercial Food Service Maintenance Practices. Journal of Food Protection, 60, 407-413. https://doi.org/10.4315/0362-028X-60.4.407

[65] Boursillon, D. and Riethmüller, V. (2007) The Safety of Wooden Cutting Boards: Remobilization of Bacteria from Pine, Beech, and Polyethylene. British Food Journal, 109, 315-322. https://doi.org/10.1108/00070700710736561

[66] Lücke, F.-K. and Skowyrska, A. (2015) Hygienic Aspects of Using Wooden and Plastic Cutting Boards, Assessed in Laboratory and Small Gastronomy Units. Journal für Verbraucherschutz und Lebensmittelsicherheit, 10, 317-322. https://doi.org/10.1007/s00003-015-0949-5

[67] Mariani, C., Briandet, R., Chamba, J.-F., Notz, E., Carnet-Pantiez, A., Eyoug, R.N. and Oulahal, N. (2007) Biofilm Ecology of Wooden Shelves Used in Ripening the French Raw Milk Smear Cheese Reblochon de Savoie. Journal of Dairy Science, 90, 1653-1661. https://doi.org/10.3168/jds.2006-190

[68] Gough, N.L. and Dodd, C.E.R. (1998) The Survival and Disinfection of Salmonella Typhimurium on Chopping Board Surfaces of Wood and Plastic. Food Control, 9, 363-368. https://doi.org/10.1016/S0956-7135(98)00127-3

[69] Zangerl, P., Matlschweiger, C., Dillinger, K. and Eliskases-Lechner, F. (2010) Survival of Listeria monocytogenes after Cleaning and Sanitation of Wooden Shelves Used for Cheese Ripening. European Journal of Wood and Wood Products, 68, 415-419. https://doi.org/10.1007/s00107-009-0381-6

[70] Miller, A.J., Brown, T. and Call, J.E. (1996) Comparison of Wooden and Polyethylene Cutting Boards: Potential for the Attachment and Removal of Bacteria from Ground Beef. Journal of Food Protection, 59, 854-858. https://doi.org/10.4315/0362-028X-59.8.854

[71] Revol-Junelles, A.-M., Miguindou-Mabiala, R., Roger-Maigné, D. and Millière, J.-B. (2005) Behavior of Escherichia Coli Cells and Bacillus Cereus Spores on Poplar Wood Crates by Impedance Measurements. Journal of Food Protection, 68, 80-84. 
https://doi.org/10.4315/0362-028X-68.1.80

[72] Moore, G., Blair, I.S. and McDowell, D.A. (2007) Recovery and Transfer of Salmonella Typhimurium from Four Different Domestic Food Contact Surfaces. Journal of Food Protection, 70, 2273-2280. https://doi.org/10.4315/0362-028X-70.10.2273

[73] Miranda, R.C. and Schaffner, D.W. (2016) Longer Contact Times Increase Cross-Contamination of Enterobacter Aerogenes from Surfaces to Food. Applied and Environmental Microbiology, 82, 6490-6496.

https://doi.org/10.1128/AEM.01838-16

[74] Dawson, P., Han, I., Cox, M., Black, C. and Simmons, L. (2007) Residence Time and Food Contact Time Effects on Transfer of Salmonella Typhimurium from Tile, Wood and Carpet: Testing the Five-Second Rule. Journal of Applied Microbiology, 102, 945-953.

[75] Mohammad, G.A. and Al-Taee, S.M. (2014) Comparison of Various Types of Cutting Boards in Bacterial Contamination. Journal of College of Education for Pure Sciences, 4, 301-308.

[76] Goh, S.G., Leili, A.-H., Kuan, C.H., Loo, Y.Y., Lye, Y.L., Chang, W.S., Soopna, P., Najwa, M.S., Tang, J.Y.H., Yaya, R., Nishibuchi, M., Nakaguchi, Y. and Son, R. (2014) Transmission of Listeria monocytogenes from Raw Chicken Meat to Cooked Chicken Meat through Cutting Boards. Food Control, 37, 51-55. https://doi.org/10.1016/j.foodcont.2013.08.030

[77] Ak, N.O., Cliver, D.O. and Kaspar, C.W. (1994) Cutting Boards of Plastic and Wood Contaminated Experimentally with Bacteria. Journal of Food Protection, 57, 16-22. https://doi.org/10.4315/0362-028X-57.1.16

[78] Ak, N.O., Cliver, D.O. and Kaspar, C.W. (1994) Decontamination of Plastic and Wooden Cutting Boards for Kitchen Use. Journal of Food Protection, 57, 23-30. https://doi.org/10.4315/0362-028X-57.1.23

[79] Imhof, R., Schwendimann, L. and Scettrini, P.R. (2017) Sanitising Wooden Boards Used for Cheese Maturation by Means of a Steam-Mediated Heating Process. Journal of Consumer Protection and Food Safety, 12, 255-263.

https://doi.org/10.1007/s00003-017-1114-0

[80] Deza, M.A., Araujo, M. and Garrido, M.J. (2007) Efficacy of Neutral Electrolyzed Water to Inactivate Escherichia Coli, Listeria monocytogenes, Pseudomonas aeruginosa, and Staphylococcus aureus on Plastic and Wooden Kitchen Cutting Boards. Journal of Food Protection, 70, 102-108. https://doi.org/10.4315/0362-028X-70.1.102

[81] DeVere, E. and Purchase, D. (2007) Effectiveness of Domestic Antibacterial Products in Decontaminating Food Contact Surfaces. Food Microbiology, 24, 425-430. https://doi.org/10.1016/j.fm.2006.07.013

[82] Acuff, G.R., Vanderzant, C., Hanna, M.O., Ehlers, J.G. and Gardner, F.A. (1986) Effects of Handling and Preparation of Turkey Products on the Survival of Campylobacter Jejuni. Journal of Food Protection, 49, 627-631.

https://doi.org/10.4315/0362-028X-49.8.627

[83] Thormar, H. and Hilmarsson, H. (2010) Killing of Campylobacter on Contaminated Plastic and Wooden Cutting Boards by Glycerol Monocaprate (Monocaprin). Letters in Applied Microbiology, 51, 319-324. https://doi.org/10.1111/j.1472-765X.2010.02898.x

[84] Al-Qadiri, H.M., Ovissipour, M., Al-Alami, N., Govindan, B.N., Shiroodi, S.G. and Rasco, B. (2016) Efficacy of Neutral Electrolyzed Water, Quaternary Ammonium and Lactic Acid-Based Solutions in Controlling Microbial Contamination of Food 
Cutting Boards Using a Manual Spraying Technique. Journal of Food Science, 81, M1177-M1183. https://doi.org/10.1111/1750-3841.13275

[85] Alañón, M.E., García-Ruíz, A., Díaz-Maroto, M.C., Pérez-Coello, M.S. and Moreno-Arribas, M.V. (2015) Antimicrobial and Antioxidant Activity of Pressurized Liquid Extracts from Oenological Woods. Food Control, 50, 581-588. https://doi.org/10.1016/j.foodcont.2014.09.043

[86] Johnston, W.H., Karchesy, J.J., Constantine, G.H. and Craig, A.M. (2001) Antimicrobial Activity of Some Pacific Northwest Woods against Anaerobic Bacteria and Yeast. Phytotherapy Research, 15, 586-588. https://doi.org/10.1002/ptr.765

[87] Schönwälder, A., Kehr, R., Wulf, A. and Smalla, K. (2002) Wooden Boards Affecting the Survival of Bacteria? Holz als Roh-und Werkstoff, 60, 249-257. https://doi.org/10.1007/s00107-002-0300-6

[88] Munir, M.T., Belloncle, C., Pailhories, H., Aviat, F., Federighi, M. and Eveillard, M. (2017) Wood as a Safe Material for Indoor Surface Construction of Hygienically Sensitive Places. Northwestern Polytechnical University Xi'an, 79-80. https://doi.org/10.1179/2042645313Y.0000000038

[89] Vainio-Kaila, T., Rautkari, L., Nordström, K., Närhi, M., Natri, O. and Kairi, M. (2013) Effect of Extractives and Thermal Modification on Antibacterial Properties of Scots Pine and Norway Spruce. International Wood Products Journal, 4, 248-252.

[90] Vainio-Kaila, T., Kyyhkynen, A., Rautkari, L. and Siitonen, A. (2015) Antibacterial Effects of Extracts of Pinus sylvestris and Picea abies against Staphylococcus Aureus, Enterococcus Faecalis, Escherichia Coli, and Streptococcus Pneumoniae. BioResources, 10, 7763-7771. https://doi.org/10.15376/biores.10.4.7763-7771

[91] Vainio-Kaila, T., Zhang, X., Hänninen, T., Kyyhkynen, A., Johansson, L.-S., Willför, S., Österberg, M., Siitonen, A. and Rautkari, L. (2017) Antibacterial Effects of Wood Structural Components and Extractives from Pinus sylvestris and Picea abies on Methicillin-Resistant Staphylococcus Aureus and Escherichia Coli O157:H7. BioResources, 12, 7601-7614.

[92] Valette, N., Perrot, T., Sormani, R., Gelhaye, E. and Morel-Rouhier, M. (2017) Antifungal Activities of Wood Extractives. Fungal Biology Reviews, 31, 113-123. https://doi.org/10.1016/j.fbr.2017.01.002

[93] Mensah, J.K., Adei, E., Adei, D. and Owusu Ansah, G. (2012) Assessment of Local Wood Species Used for the Manufacture of Cookware and the Perception of Chemical Benefits and Chemical Hazards Associated with Their Use in Kumasi, Ghana. Journal of Ethnobiology and Ethnomedicine, 8, 46. https://doi.org/10.1186/1746-4269-8-46

[94] Kirkeskov, L., Witterseh, T., Funch, L.W., Kristiansen, E., Mølhave, L., Hansen, M.K. and Knudsen, B.B. (2009) Health Evaluation of Volatile Organic Compound (VOC) Emission from Exotic Wood Products. Indoor Air, 19, 45-57. https://doi.org/10.1111/j.1600-0668.2008.00560.x

[95] Munir, M.T., Belloncle, C., Pailhoriès, H., Eveillard, M., Aviat, F. and Federighi, M. (2018) Survival of Nosocomial Pathogens on Maritime Pine and European Fir Wood. Proceedings of the 5 th International Conference on Processing Technologies for the Forest and Bio-Based Products Industries, Freising/Munich, 213-217.

[96] Ahmad, A., Kaleem, M., Ahmed, Z. and Shafiq, H. (2015) Therapeutic Potential of Flavonoids and Their Mechanism of Action against Microbial and Viral Infections-A Review. Food Research International, 77, 221-235. https://doi.org/10.1016/j.foodres.2015.06.021

[97] Silva, N.C.C. and Fernandes Júnior, A. (2010) Biological Properties of Medicinal 
Plants: A Review of Their Antimicrobial Activity. Journal of Venomous Animals and Toxins including Tropical Diseases, 16, 402-413. https://doi.org/10.1590/S1678-91992010000300006

[98] Teodoro, G.R., Ellepola, K., Seneviratne, C.J. and Koga-Ito, C.Y. (2015) Potential Use of Phenolic Acids as Anti-Candida Agents: A Review. Frontiers in Microbiolo$g y, 6,1420$. https://doi.org/10.3389/fmicb.2015.01420

[99] Silhavy, T.J., Kahne, D. and Walker, S. (2010) The Bacterial Cell Envelope. Cold Spring Harbor Perspectives in Biology, 2, a000414. https://doi.org/10.1101/cshperspect.a000414

[100] Riaz, A., Umar, S., Munir, M.T. and Tariq, M. (2017) Replacements of Antibiotics in the Control of Necrotic Enteritis: A Review. Science Letters, 5, 208-216. 